\title{
Difference in physiological responses of growth, photosynthesis and calcification of the coccolithophore Emiliania huxleyi to acidification by acid and $\mathrm{CO}_{2}$ enrichment
}

\author{
Shin-ya Fukuda $\cdot$ Yurina Suzuki • Yoshihiro Shiraiwa
}

Received: 2 September 2013/Accepted: 21 January 2014/Published online: 6 February 2014

(C) The Author(s) 2014. This article is published with open access at Springerlink.com

\begin{abstract}
Ocean acidification, one of the great global environmental issues at present, is expected to result in serious damage on marine calcareous organisms such as corals and calcifying algae, which potentially release huge amounts of $\mathrm{CO}_{2}$ from the ocean to the atmosphere. The coccolithophore, Emiliania huxleyi (Haptophyceae), which frequently produces blooms, has greatly contributed to the biological $\mathrm{CO}_{2}$ pump. This study was aimed at analyzing effects of how E. huxleyi responds to acidification. Acidification was performed by two methods, namely by just adding $\mathrm{HCl}$ under bubbling ordinary air at 8.2-8.4, 7.6-7.8 and 7.1-7.3 (acidification by $\mathrm{HCl}$ ) and by bubbling with ordinary air or with increased $\mathrm{CO}_{2}$ concentration such as 406,816 and $1,192 \mathrm{ppm}$ that maintained $\mathrm{pH}$ of the medium at 8.0-8.3, 7.6-7.9 and 7.5-7.7 (acidification by $\mathrm{CO}_{2}$ enrichment). As a result, cell growth and cellular calcification of $E$. huxleyi were strongly damaged by acidification by $\mathrm{HCl}$, but not by acidification by $\mathrm{CO}_{2}$ enrichment. The activities of photosystems such as $F_{\mathrm{v}} / F_{\mathrm{m}}$ and $\phi$ PSII were not affected by any acidification conditions while photosynthetic $\mathrm{O}_{2}$ evolution was slightly stimulated. A ${ }^{45} \mathrm{Ca}$ radiotracer experiment revealed that $\mathrm{Ca}^{2+}$-uptake was strongly suppressed by acidification with $\mathrm{HCl}$. This suppression recovered after increasing the dissolved inorganic carbon (DIC) concentration and further stimulated by an additional increase in DIC concentration. The production of storage and coccolith polysaccharides was increased by
\end{abstract}

S. Fukuda · Y. Suzuki · Y. Shiraiwa $(\square)$

Faculty of Life and Environmental Sciences, University of

Tsukuba, 1-1-1 Tennodai, Tsukuba, Japan

e-mail: emilhux@biol.tsukuba.ac.jp

Y. Shiraiwa

CREST, JST, 1-1-1 Tennodai, Tsukuba, Japan acidification by $\mathrm{HCl}$ and also highly stimulated by acidification with $\mathrm{CO}_{2}$ enrichment. The present study clearly showed that the coccolithophore, E. huxleyi, has an ability to respond positively to acidification with $\mathrm{CO}_{2}$ enrichment, but not just acidification.

Keywords Acidification $\cdot \mathrm{CO}_{2}$ enrichment . Calcification - Emiliania huxleyi $\cdot \mathrm{pH}$ effect . Photosynthesis

\section{Introduction}

The increase in atmospheric $\mathrm{CO}_{2}$ concentration is now recognized to have increased ocean acidification (Orr et al. 2005; Zeebe et al. 2008). Oceanic pH has already decreased $0.1 \mathrm{U}$ ever since the industrial revolution in the eighteenth century, and it is speculated to decrease $0.5 \mathrm{U}$ further by the end of the twenty-first century according to IPCC scenario. The $\mathrm{pH}$ of the surface ocean is estimated to decrease by $0.3-0.5$ and $0.7-0.77 \mathrm{U}$ relative to the present level by 2,100 (pH 7.6-7.9) and 2,300 (pH 7.33-7.5), respectively (Caldeira and Wickett 2003; Ross et al. 2011). Such rapid ocean acidification is believed to have negative influences on marine organism with calcifying organisms as prime targets for strong damage by acidification (Feely et al. 2004), e.g., the bleaching and reduction of coral reefs (Gattuso et al. 1998; Kleypas et al. 1999; Hoegh-Guldberg et al. 2007; Anthony et al. 2008; Kuffner et al. 2008; Veron et al. 2009). In addition, the shell of gastropod, Littorina littorea, and foraminifera are shown to lose hardness by acidification (Bibby et al. 2007; Bijma et al. 2002). The fertilization rate of sea urchin, Psammechinus miliaris, declined with acidification (Miles et al. 2007). Such influence of oceanic acidification is expected to affect the 
entire ecosystem and damage the oceanic environment. However, even under such circumstances, actual events caused by acidification have not been investigated thoroughly in individual organisms (Richier et al. 2010).

In particular, a marine calcifying haptophycean alga, Emiliania huxleyi, is affected by ocean acidification (Iglesias-Rodriguez et al. 2008; Langer et al. 2006; Riebesell et al. 2000) because E. huxleyi forms cell-covering, calcium carbonate crystals, called coccoliths. The alga is known to distribute widely in the world ocean, fix a large amount of carbon, produce a huge biomass and carry carbon from sea surface to the sediment by the biological $\mathrm{CO}_{2}$ pump (Liu et al. 2009). Therefore, E. huxleyi can be said to have played very important roles in the global carbon cycle. Riebesell et al. (2000) reported a reduction in calcification by $E$. huxleyi under future scenarios on ocean acidification. However, Iglesias-Rodriguez et al. (2008) observed enhanced calcification under elevated $\mathrm{pCO}_{2}$ in $E$. huxleyi. Hoppe et al. (2011) reported that E. huxleyi shows identical responses to elevated $\mathrm{pCO}_{2}$ in total alkalinity (TA) and dissolved inorganic carbon (DIC) manipulations. They also showed that different experimental protocols (e.g., continuous bubbling versus pre-bubbled) can lead to change in growth rates and other ecophysiological parameters.

The coccolithophore E. huxleyi has influenced the global climate for over 200 million years and therefore is thought to have played critical roles in the global carbon cycle. Even in the present ocean, the algae are widely distributed globally and it is well known that they fix a large amount of carbon, produce a huge biomass and carry carbon from the sea surface to the sediment by the biological $\mathrm{CO}_{2}$ pump (Liu et al. 2009). Recently, Read et al. (2013) reported the first haptophyte reference genome, from $E$. huxleyi CCMP1516, and sequences from 13 additional isolates. It revealed that a pan genome (core genes plus genes distributed variably between strains) is probably supported by an atypical compliment of respective sequences in the genome. They assumed that such a wide variation of genomes in E. huxleyi seems to be the reason for forming large-scale episodic blooms under a wide variety of environmental conditions.

In this study, we investigated the physiological response of the coccolithophore E. huxleyi to acidification by experimental acid enrichment (acidification by $\mathrm{HCl}$ ) and by ventilation of air with elevated concentration of $\mathrm{CO}_{2}$ (acidification by $\mathrm{CO}_{2}$ enrichment). These conditions are not exactly the same as the ocean acidification conditions being observed in the ocean, but will give important information on how E. huxleyi will respond to acidification. Finally, we clearly show that just acidification caused by $\mathrm{HCl}$ is disadvantageous to $E$. huxleyi, but acidification by $\mathrm{CO}_{2}$ enrichment induced positive influence on photosynthesis and calcification of the organism. This study also proved clearly that the suppression of intracellular calcification by acidification in the coccolithophore is due to the reduction of $\mathrm{HCO}_{3}{ }^{-}$supply, which is the substrate for intracellular calcium carbonate crystal production, because the suppression of calcification recovered following additional supply of bicarbonate ions.

\section{Materials and methods}

Material and culture conditions

The strain (NIES 837) of the coccolithophore E. huxleyi (Lohmann) Hay and Mohler (Haptophyta) used in this study was collected by Dr. I. Inouye in the South Pacific Ocean in 1990 and has been maintained at $20{ }^{\circ} \mathrm{C}$ under 16-h light/8-h dark regime in our laboratory. Cells were maintained in natural seawater for stock culture. For experimental culture, the medium used was an artificial seawater (Marine Art SF-1; produced by Tomita Seiyaku Co., Ltd., Tokushima, Japan, distributed by Osaka Yakken Co., Ltd., Osaka, Japan) enriched with a micronutrient mixture of the Erd-Schreiber's medium (ESM) in which soil extracts are replaced with $10 \mathrm{nM}$ sodium selenite according to Danbara and Shiraiwa (1999). ESM enrichment contains $28.7 \mu \mathrm{M}$ (final concentration in the medium) $\mathrm{K}_{2} \mathrm{HPO}_{4}$, but not in the Marine Art SF. In all acidification experiments, cells were grown in the artificial seawater containing EMS medium (MA/ESM medium) under constant illumination at $100 \mu \mathrm{mol}$ photons $\mathrm{m}^{-2} \mathrm{~s}^{-1}$ and $20^{\circ} \mathrm{C}$ (standard condition). To avoid large changes in the $\mathrm{pH}$ of the medium during culture, both HEPES and Tris-buffer (final concentration, $10 \mathrm{mM}$ each) were added to the medium by considering those buffers' buffering ability and pKa values.

Bubbling cultures with air and air containing elevated concentration of $\mathrm{CO}_{2}$

Tanks containing air with elevated concentrations of $\mathrm{CO}_{2}$, namely 406, 816 and $1192 \mathrm{ppm}$, were purchased from the company, Suzuki Shokan Ltd., Tsukuba, Japan. First, those gasses were bubbled through MA/EMS medium containing HEPES- and Tris-buffers (10 $\mathrm{mM}$ each) for $15 \mathrm{~h}$ as prebubbling for attaining equilibrium of $\mathrm{CO}_{2}$ between the bubbled gasses and the medium. The concentrations of respective DIC species in the medium shown in Fig. 1 and 6 were calculated according to Leuker et al. (2000) and $\mathrm{CO}_{2} \mathrm{SYS}$, respectively. On the other hand, algal cells were grown separately with air in the MA/ESM medium under constant illumination at $100 \mu \mathrm{mol} \mathrm{m} \mathrm{s}^{-2}$ and $20^{\circ} \mathrm{C}$ for 3 days. And then, an aliquot of the algal suspension was 

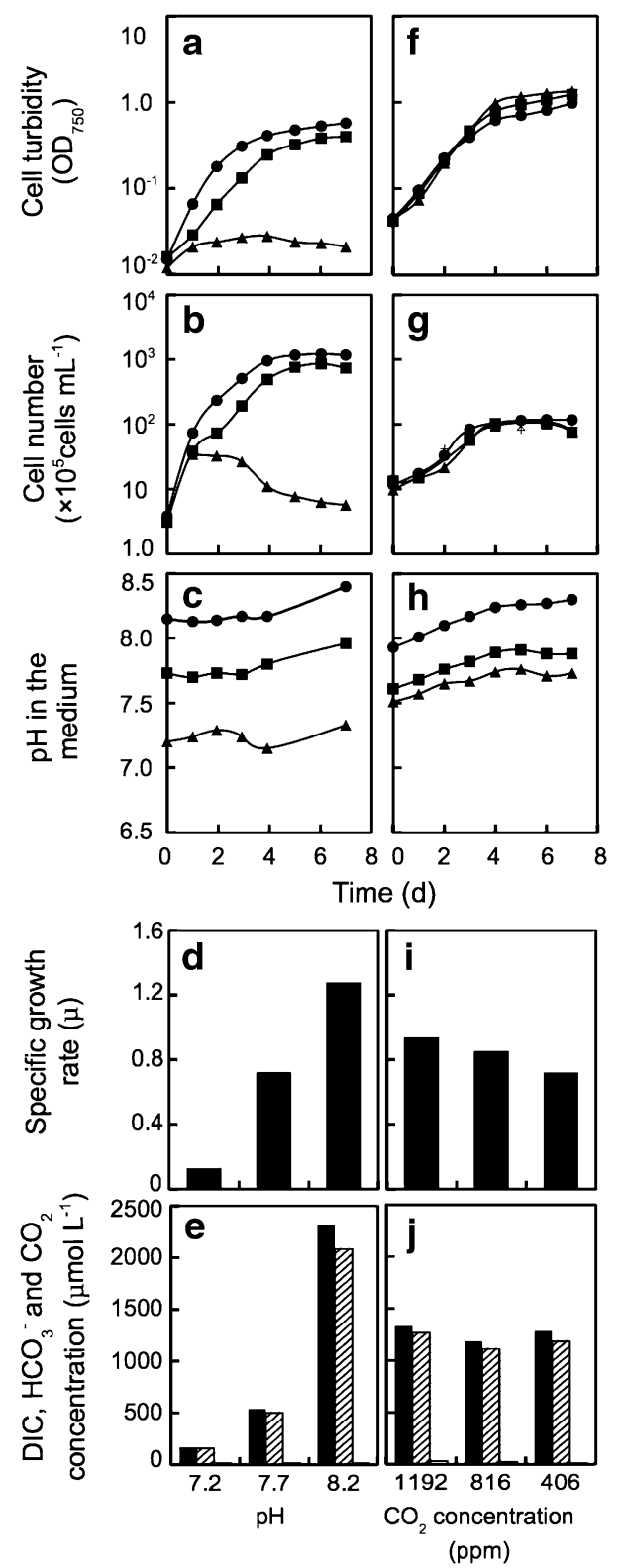

Fig. 1 Effect of the acidification by $\mathrm{HCl}(\mathbf{a}-\mathbf{e})$ and the ocean acidification conditions by elevating $\mathrm{pCO}_{2}(\mathbf{f}-\mathbf{j})$ on the cell growth of the coccolithophore E. huxleyi. Before experiments, all cells had been grown at pH 8.2 under the bubbling of air containing $400 \mathrm{ppm} \mathrm{CO}_{2}$. Temperature was $20{ }^{\circ} \mathrm{C}$. $\mathbf{a}, \mathbf{f}$, Change in turbidity; $\mathbf{b}, \mathbf{g}$ change in cell number; $\mathbf{c}, \mathbf{h} \mathrm{H}$ in the medium. Initial $\mathrm{pHs}$ were set at 8.2 in $\mathbf{a}$ (closed circles), 7.7 in closed squares and 7.2 in closed triangles by $\mathrm{HCl}(\mathbf{a}-$ c) and at 7.9 in closed circles, 7.6 in closed squares and 7.5 closed triangles by elevating $\mathrm{pCO}_{2}(\mathbf{f}-\mathbf{h})$. d, i Specific growth rates $(\mu)$ calculated on the basis of cell number; $\mathbf{e}, \mathbf{j}$ inorganic carbon concentrations in the medium at each $\mathrm{pH}$ and the elevated $\mathrm{pCO}_{2}$ concentration at 1 day. $\mathrm{CO}_{2}$ concentration was set at $15 \mu \mathrm{mol} \mathrm{L} \mathrm{L}^{-1}$ in all the conditions (right column). Solid (left) and stripe (middle) columns indicate total DIC and $\mathrm{HCO}_{3}{ }^{-}$concentrations, respectively. DIC, bicarbonate and $\mathrm{CO}_{2}$ concentrations were calculated by a kind help of Dr. Midorikawa according to Leuker et al. (2000) transferred to the previously prepared medium of which $\mathrm{pH}$ and $p \mathrm{CO}_{2}$ were already set by adding $\mathrm{HCl}$ or bubbling of air containing elevated $\mathrm{CO}_{2}$, as described above.

Determination of the specific growth rate and microscopic observation

Cell turbidity of the culture was determined by measuring $\mathrm{OD}_{750}$ using a spectrophotometer (UV-1700, Shimadzu, Kyoto, Japan). Cell number was determined under a microscope by counting cells on a ready-made glass slide using a microscopic camera system and a counter. The specific growth rate $(\mu)$ was calculated by the equation of $\mu=\ln \left[\left(m_{t_{1}}-m_{t_{1}}\right) /\left(t_{2}-t_{1}\right)\right]$, where $m_{\mathrm{x}}$ represents cell number at arbitrary time $t_{1}$ and $t_{2}\left(t_{2}>t_{1}\right)$ during the logarithmic growth phase. Coccoliths covering cells were visualized under polarized light by a microscope (Olympus Ltd., Tokyo, Japan) equipped with a fluorescence microscope digital camera (Keyence, Osaka, Japan).

\section{Determination of photosynthetic activity}

The algal cells were harvested from the culture and then centrifuged $\left(700 \times g\right.$ for $10 \mathrm{~min}$ at $\left.15{ }^{\circ} \mathrm{C}\right)$ to obtain a cell pellet. After suspending cells in adequate buffers, photosynthetic $\mathrm{O}_{2}$ evolution activity was determined by a Clarktype oxygen electrode (Rank Brothers Co., Ltd., UK). The light intensity and temperature were maintained at $270 \mu$ mol photons $\mathrm{m}^{-2} \mathrm{~s}^{-1}$ and $25^{\circ} \mathrm{C}$, respectively. The light source was a white LED lamp (Model HLV-24SW-3W, CCS, Kyoto, Japan).

Determination of photosystem activity expressed with chlorophyll fluorescence parameters

Photosystems of E. huxleyi were characterized by the chlorophyll fluorescence method. First, chlorophyll concentration of cells was determined in $90 \%$ methanol extracts by a spectrophotometer (UV-1700, Shimadzu, Kyoto, Japan) according to published procedures (Jeffrey 1972). Then algal concentration was adjusted to $5.0 \mu \mathrm{g} \mathrm{Chl} \mathrm{mL}^{-1}$ in the MA/ESM medium (final phosphate concentration, $28.7 \mu \mathrm{M})$ at different pHs (7.2-8.2) for measurements. Photosystem activity was determined using a FluorCam (MF 701, Photon Systems Instruments, Bruno, Czech Republic), and the parameters of $F_{\mathrm{v}} / F_{\mathrm{m}}$ and $\phi$ PSII were calculated by manufactured software attached to the apparatus. The duration and intensity of excitation light were $20 \mathrm{~min}$ and $100 \mu \mathrm{mol}$ photons $\mathrm{m}^{-2} \mathrm{~s}^{-1}$, respectively, and of measured saturated pulsed light were 
$800 \mathrm{~ms}$ and $2,000 \mu \mathrm{mol}$ photons $\mathrm{m}^{-2} \mathrm{~s}^{-1}$, respectively. Dissolved inorganic carbon (DIC) concentration was $2 \mathrm{mM}$, which was equilibrated with atmospheric $\mathrm{CO}_{2}$ concentration at $\mathrm{pH} 8.2$.

${ }^{45}$ Ca uptake assay

Effect of $\mathrm{pH}$ on calcification was tested by a radiotracer method. The cells were harvested by centrifugation $\left(700 \times g\right.$ for $10 \mathrm{~min}$ at $15^{\circ} \mathrm{C}$ ) and re-suspended into the fresh experimental culture medium. The $\mathrm{pH}$ of the medium was adjusted at either $\mathrm{pH} 7.2,7.7$ or 8.2 by adding an aliquot of $0.2 \mathrm{~N} \mathrm{HCl}$. An aliquot of ${ }^{45} \mathrm{CaCl}_{2}$ solution (Perkin-Elmer, Inc., Waltham, MA, USA) was directly injected into algal cell culture. Final concentration and the specific radioactivity of ${ }^{45} \mathrm{Ca}$ in the medium were $10 \mathrm{mM}$ and $20 \mathrm{MBq} \mathrm{mmol}^{-1}$, respectively. The algal suspension was continuously bubbled with ordinary air at a speed of $100 \mathrm{~mL} \mathrm{~min}{ }^{-1}$. Subsequent experimental procedure for the determination of ${ }^{45} \mathrm{Ca}$ uptake activity was according to the method of Kayano and Shiraiwa (2009). According to our previous results in the same strain of $E$. huxleyi, more than $95 \%$ of calcium absorbed by cells is utilized for calcification (Satoh et al. 2009) and therefore the measurement of ${ }^{45} \mathrm{Ca}$-uptake could be used as a good parameter for calcification activity in this study.

\section{Assays}

As the coccolith contains the coccolith polysaccharides, which are acid polysaccharides composed of uronic acids (Kayano and Shiraiwa 2009), uronic acid content was used as a parameter of acid polysaccharide (AP) production. The carbazole- $\mathrm{H}_{2} \mathrm{SO}_{4}$ assay (Bitter and Muir 1962) was used for the determination of uronic acid content using 0-90 $\mu \mathrm{g} \mathrm{mL}^{-1}$ glucuronic acid (Chugai Pharmaceutical Co., Ltd., Tokyo, Japan) as a standard for calibration.

The amount of total polysaccharides (TP) included both AP and neutral polysaccharides (NP) composed of reducing sugars. TP was estimated as total sugars using a phenol- $\mathrm{H}_{2} \mathrm{SO}_{4}$ assay using $0-90 \mu \mathrm{g} \mathrm{mL}^{-1}$ glucose as a standard for calibration (Hodge and Hofreiter 1962). Then, the amount of NP was calculated by TP - AP.

The polysaccharides were analyzed by SDS-PAGE on a $15 \%$ acrylamide gel. After electrophoresis, the gels were stained with Stains-all (Applichem GmbH, A1400.0001, Cheshire, USA) and Alcian blue (Sigma-Aldrich, A526810G, Missouri, USA) for determining TP and AP, respectively. The quantitative analysis of the protein used BIORAD DC protein Assay kit (Bio-Rad Laboratories AB, 500-0111, Oslo, Norway) using albumin as a standard for calibration.

\section{Results}

Effect of acidification on the growth of E. huxleyi

The growth curve of E. huxleyi determined by cell number and turbidity showed clear suppression by acidification with $\mathrm{HCl}$ under the aeration of ordinary air (Fig. 1a, b). The $\mathrm{pH}$ values of the medium in three cultures were maintained nearly constant with slight increases from 8.2 to 8.4 ( 8.2 for first 4 days), 7.7 to 7.9 ( 7.7 for first 4 days) and 7.2 to 7.3 (ca. 7.2 for first 4 days) during 7 days (Fig. 1c). The $\mathrm{pH}$ values for first 4 days were used to express culture conditions in the text. The specific growth rate $(\mu)$ decreased by acidification ca. 30 and $60 \%$ at $\mathrm{pH} 7.7$ and 7.2, respectively, in comparison with that at $\mathrm{pH} 8.2$ (Fig. 1d). Cell growth at $\mathrm{pH} 7.2$ was rapidly and strongly suppressed in a day, and then, cells were destroyed (Fig. 1a, b). The concentrations of total DIC and bicarbonate ions at $\mathrm{pH} 7.7$ and 7.2 cultures were 75 and $90 \%$ lower than that at $\mathrm{pH} 8.2$ culture (Fig. 1e). As dissolved $\mathrm{CO}_{2}\left(\mathrm{dCO}_{2}\right)$ concentration in the medium is maintained as a constant according to the Henry's law under bubbling of air, the suppression of growth at low pHs should be due to the combination of acidification effect and the decrease in $\mathrm{HCO}_{3}{ }^{-}$concentrations equilibrated with air (Fig. 1e).

On the other hand, the growth of E. huxleyi was almost the same among different $\mathrm{CO}_{2}$ concentrations and $\mathrm{pHs}$ when acidification was performed by the bubbling of air containing elevated $\mathrm{CO}_{2}$ concentration such as 406,816 and $1,192 \mathrm{ppm}$ (acidification by $\mathrm{CO}_{2}$ enrichment) (Fig. 1f, g). During the culture for $7 \mathrm{~d}$, the $\mathrm{pH}$ of the medium was maintained at $8.0-8.3,7.6-7.9$ and $7.5-7.7$ by the bubbling of air containing 406, 816 and $1,192 \mathrm{ppm} \mathrm{CO}_{2}$, respectively (Fig. 1h). The specific growth rate $(\mu)$ was slightly higher ca. 15 and $25 \%$ at 816 and $1,192 \mathrm{ppm} \mathrm{CO}_{2}$, respectively, in comparison with that at $406 \mathrm{ppm} \mathrm{CO}_{2}$ (Fig. 1i). Under such conditions, total DIC and bicarbonate concentrations were almost the same among the three different $\mathrm{CO}_{2}$ conditions resulting in different pHs (Fig. 1h) where $\mathrm{dCO}_{2}$ concentrations were increased according to the elevation of $\mathrm{CO}_{2}$ concentration (Fig. 1j).

Effect of acidification on photosynthetic activity in E. huxleyi

The photosynthetic $\mathrm{O}_{2}$ evolution activity was not affected when $\mathrm{pH}$ of the medium decreased (Fig. 2a-c, g), suggesting that photosynthetic machinery was hardly damaged by acidification with $\mathrm{HCl}$. However, photosynthetic activity changed during the 7-day experiment at every $\mathrm{pH}$ tested. Although the reason is unclear yet, it maybe associated with the depletion of inorganic phosphate from the medium during growth, according to our previous study (Satoh et al. 
Fig. 2 Effect of the acidification by $\mathrm{HCl}(\mathbf{a}-\mathbf{c})$ and the ocean acidification conditions by elevating $\mathrm{pCO}_{2}$ (d-f) on the changes in photosynthetic $\mathrm{O}_{2}$ evolution activity of the coccolithophore E. huxleyi. Experimental conditions for acclimation (indicated in the figure) were same as shown in Fig. 1. The rate of photosynthetic $\mathrm{O}_{2}$ evolution was determined using a Clark-type $\mathrm{O}_{2}$ electrode at the light intensity of $270 \mu \mathrm{mol}$ photons $\mathrm{m}^{-2} \mathrm{~s}^{-1}$ and $25{ }^{\circ} \mathrm{C}$ which are the optimum conditions. The values are average of three experiments $(n=3)$

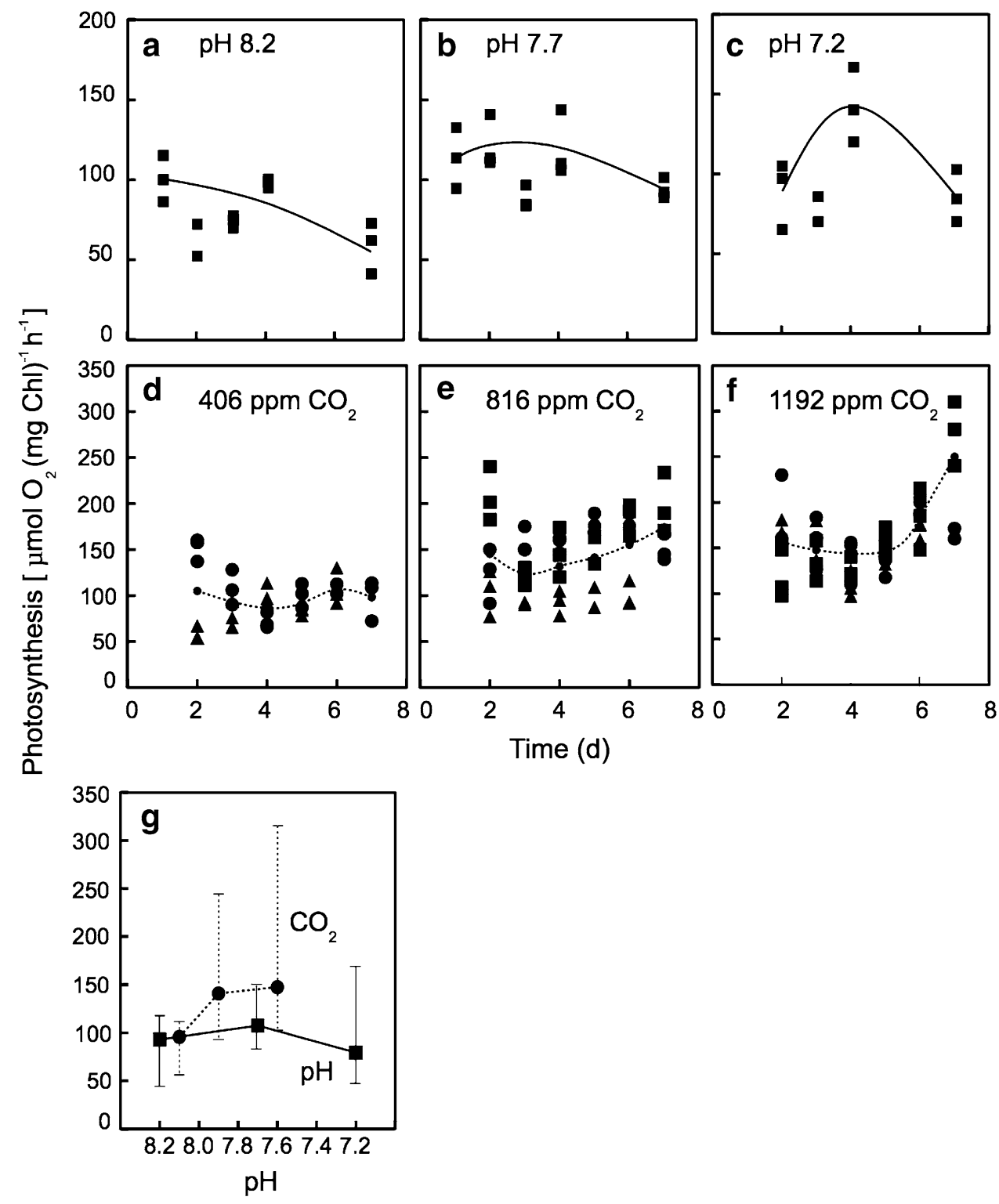

2009). Photosynthetic $\mathrm{O}_{2}$ evolution activity was slightly higher at higher $\mathrm{CO}_{2}$ concentration when compared among the 406,816 and $1,192 \mathrm{ppm} \mathrm{CO}_{2}$ experiments, where $\mathrm{pH}$ values were maintained at 7.9-8.3, 7.6-7.9 and 7.5-7.7 (Fig. 2d-f, g). The highest average value of photosynthetic $\mathrm{O}_{2}$ evolution was $150 \mu \mathrm{mol}(\mathrm{mg} \mathrm{Chl})^{-1} \mathrm{~h}^{-1}$ at $\mathrm{pH}$ 7.5-7.7, which was attained by the bubbling of air containing $1,192 \mathrm{ppm} \mathrm{CO}_{2}$ (Fig. 2g). These results show that the response of photosynthetic activity to $\mathrm{pH}$ change was almost the same, irrespective of the method of how $\mathrm{pH}$ was decreased, namely by adding $\mathrm{HCl}$ or bubbling air with elevated $\mathrm{CO}_{2}$.

The activities of the photosystems were determined by measuring $F_{\mathrm{v}} / F_{\mathrm{m}}$, which reflects the state of photosystem II (Demmig and Bjorkman 1987) and $\phi$ PSII, which is an index of the electron transport activity of the whole photosystem (Genty et al. 1989). The results indicate that the photosystem parameters determined were not changed, namely almost the same, during the 6-day experiment between $\mathrm{pH} 7.7$ and 8.2 (Fig. 3a, b). On the other hand, $F_{\mathrm{v}} / F_{\mathrm{m}}$ decreased similarly after 3 days under all tested $\mathrm{CO}_{2}$ conditions when $\mathrm{pH}$ was set by the bubbling of air containing various $\mathrm{CO}_{2}$ (Fig. $3 \mathrm{c}$, e). Under the same conditions, $\phi$ PSII was maintained almost constant for 6 days after rapidly decreasing during the first 2 days at 406 and $816 \mathrm{ppm} \mathrm{CO}_{2}$ conditions (Fig. 3c, d). There are no data on 0 day since the measurement of photosystem activities in the $\mathrm{CO}_{2}$ ventilation was begun after 1 day.

Effect of acidification on coccolith production and calcification by $E$. huxleyi

Polarized light microscopic observations clearly showed that coccolith production was strongly suppressed when 
Fig. 3 Effect of the acidification by $\mathrm{HCl}(\mathbf{a}, \mathbf{b})$ and the ocean acidification conditions by elevating $p \mathrm{CO}_{2}$ (c-e) on the changes in the parameters of photosystem activity such as $F_{\mathrm{v}} / F_{\mathrm{m}}$ and $\phi$ PSII during growth of the coccolithophore E. huxleyi. The chlorophyll fluorescence parameters were determined by Fluorcam, as described in "Materials and methods." Solid line (circles), $F_{\mathrm{v}} / F_{\mathrm{m}}$; dotted line (square), фPSII. Error bars $\pm \mathrm{SD}(n=3)$

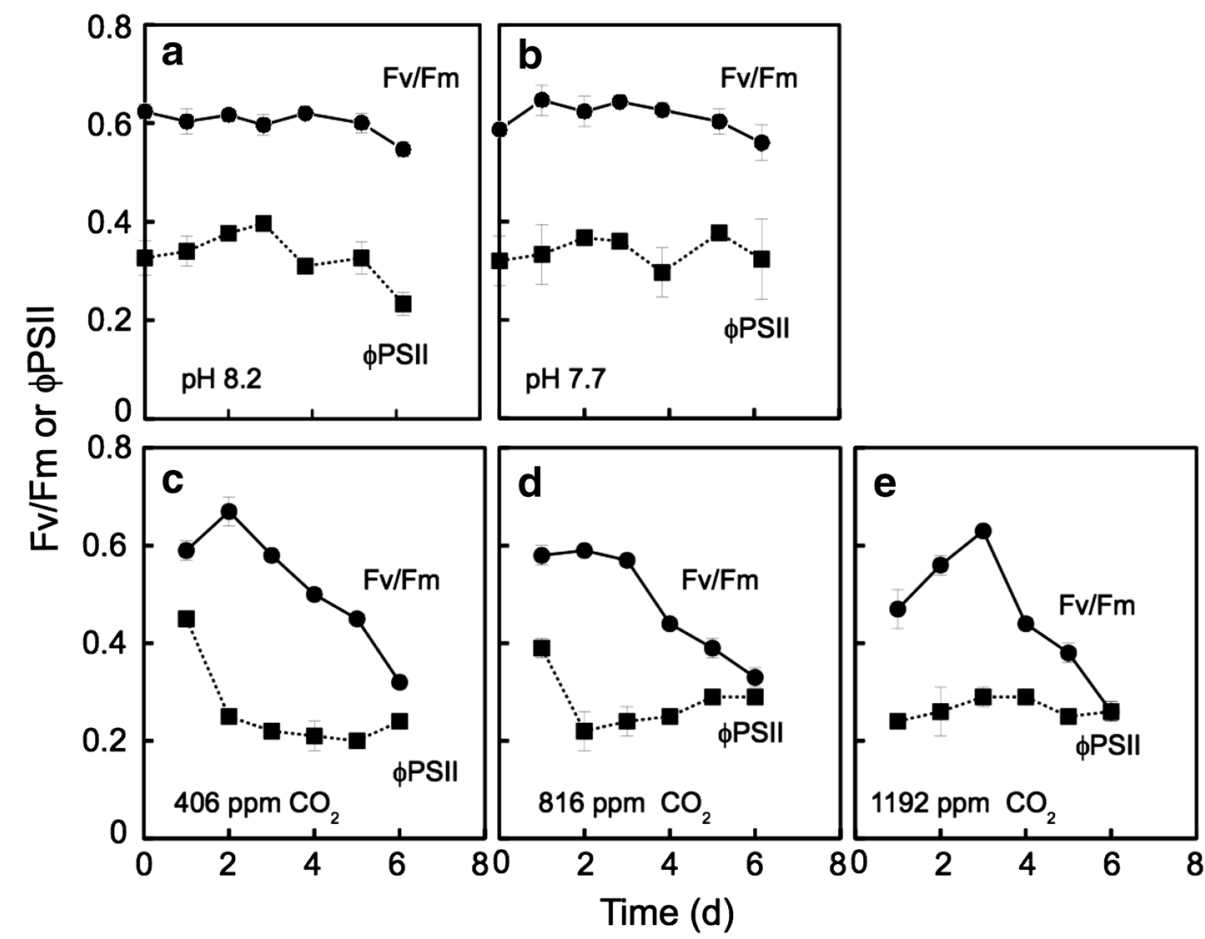

acidification was performed by $\mathrm{HCl}$ from 8.2 to $\mathrm{pH} 7.7$ and 7.2 (Fig. 4a). In contrast, coccolith production was strongly stimulated and accompanied by an increase in cell size when $\mathrm{pH}$ was maintained at 8.0-8.3, 7.6-7.9 and 7.5-7.7 by the bubbling air containing various $\mathrm{CO}_{2}$ concentrations with 406, 816 and 1,192 ppm, respectively (Fig. 4b).

E. huxleyi needs to incorporate and accumulate calcium and bicarbonate ion as substrates for intracellular coccolith production into the coccolith vesicles within the coccolithophore cells. The rate of ${ }^{45} \mathrm{Ca}$-incorporation activity was strongly suppressed to 22 and $7 \%$ at 7.7 and 7.2, respectively, in comparison with that of $\mathrm{pH} 8.2$ when $\mathrm{pH}$ values were set by acidification with $\mathrm{HCl}$ under continuous bubbling of ordinary air (Fig. 5). When the concentration of $\mathrm{CO}_{2}$ dissolved in the solution is equilibrated with atmospheric air, bicarbonate concentration is calculated to be almost the same between pHs 8.2 and 7.7, but carbonate concentration is much higher at pH 8.2 than 7.7 (Fig. 6d). These data clearly show that ${ }^{45} \mathrm{Ca}$-incorporation into cells was greatly diminished by acidification with $\mathrm{HCl}$, although the concentration of bicarbonate, the substrate to be absorbed by cells for intracellular calcification (Sekino and Shiraiwa 1994), was the same at both pHs.

On the other hand, ${ }^{45} \mathrm{Ca}$-incorporation activity was stimulated by the addition of DIC $\left(\mathrm{NaHCO}_{3}\right)$ regardless of concentration (Fig. 6a, b). Under such conditions, the ${ }^{45} \mathrm{Ca}-$ uptake activity was largely stimulated and saturated with

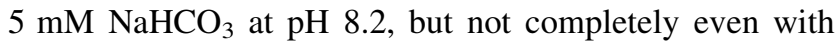
$10 \mathrm{mM}$ at $\mathrm{pH} 7.7$ while the extent of suppression by acidification was the largest at 1-2 mM DIC (Fig. 6c).
These results indicate that the suppression of ${ }^{45} \mathrm{Ca}$-uptake by acidification with $\mathrm{HCl}$ can be recovered by the addition of $\mathrm{NaHCO}_{3}$, namely by the increase in bicarbonate concentration.

Effect of acidification on the production of coccolith polysaccharides by E. huxleyi

Acidification by $\mathrm{CO}_{2}$ enrichment stimulated the production of cellular contents of photosynthetic storage products such as neutral (NP) and acid (AP) polysaccharides, which are located in the cytoplasm and coccoliths, respectively, at $\mathrm{pH}$ 7.7 in comparison with $\mathrm{pH} 8.2$ (Fig. 7a, b). On the other hand, the content of those polysaccharides was remarkably increased when acidification was attained by $\mathrm{CO}_{2}$ enrichment (Fig. 7d-f). The quantitative analytical data of NP and AP were also confirmed by SDS-PAGE images (Fig. 7c, g). The ratio of the amount of AP/NP was not affected by acidification with $\mathrm{HCl}$ (Fig. 7a, b), but NP production was more stimulated by acidification with $\mathrm{CO}_{2}$ enrichment (Fig. 7d-f).

\section{Discussion}

According to the IPCC scenario, oceanic $\mathrm{pH}$ is estimated to decrease $0.5 \mathrm{U}$, namely to $\mathrm{pH} 7.7$, by 2100 (IPCC 2007). In addition to the effects of atmospheric $\mathrm{CO}_{2}$ elevation, acidification also can be seen at shallow coastal sites of volcanic $\mathrm{CO}_{2}$ vents. Along gradients of normal $\mathrm{pH}(8.1-8.2)$ to 


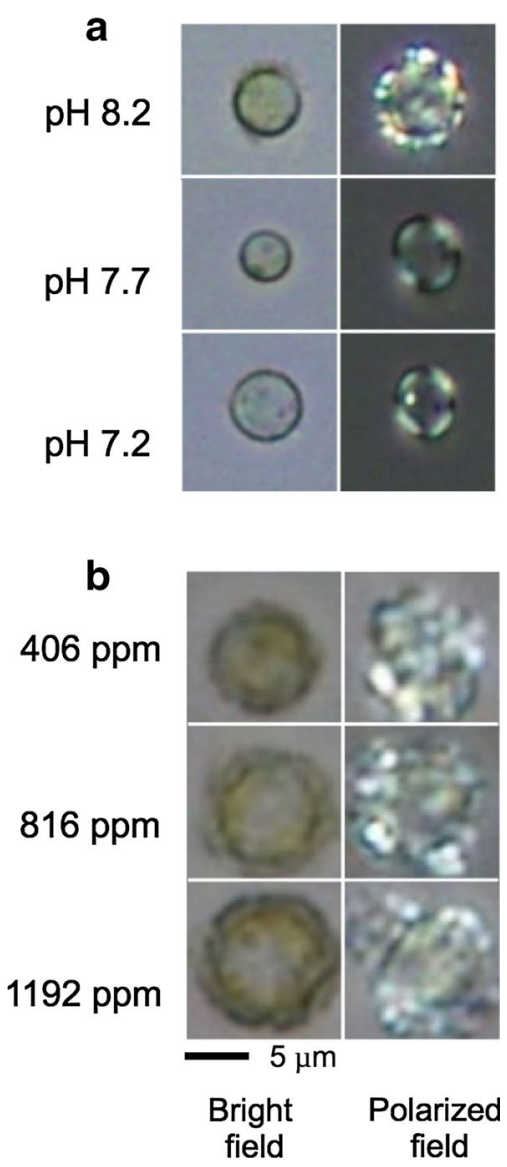

Fig. 4 Effect of the acidification by $\mathrm{HCl}$ (a) and the ocean acidification conditions by elevating $p \mathrm{CO}_{2}$ (b) on the microscopic images for coccolith production and cell size of the coccolithophore E. huxleyi. The cells were grown for 12 days under each condition. Experimental conditions for acclimation (indicated in the figure) were same as shown in Fig. 1

lowered $\mathrm{pH}$ (7.8-7.9, lowest 7.4-7.5), typical rocky shore communities with abundant calcareous organisms shifted to communities lacking scleractinian corals with significant reductions in sea urchin and coralline algal abundance (HallSpencer et al. 2008). If it happens in the surface ocean, coccolithophores will also be damaged and such damage of the primary producers in the ocean will change the composition of the global phytoplankton community and ecosystems. There are various views on the effect that ocean acidification has on calcification of the coccolithophore $E$. huxleyi. Algal growth was reported to be suppressed by acidification in coccolithophores, e.g., the decrease in the specific growth rate of coccolithophores at $\mathrm{pH}$ values below 8.0 (Swift and Taylor 1966). Iglesias-Rodriguez et al. (2008) reported that promotion of the calcification would happen by increase of the $\mathrm{CO}_{2}$. In contrast, Riebesell et al. (2000) described that the formation of the coccoliths will be inhibited by acidification.

In this study, we intended to compare the difference of acidification effect between acidification by acid supply

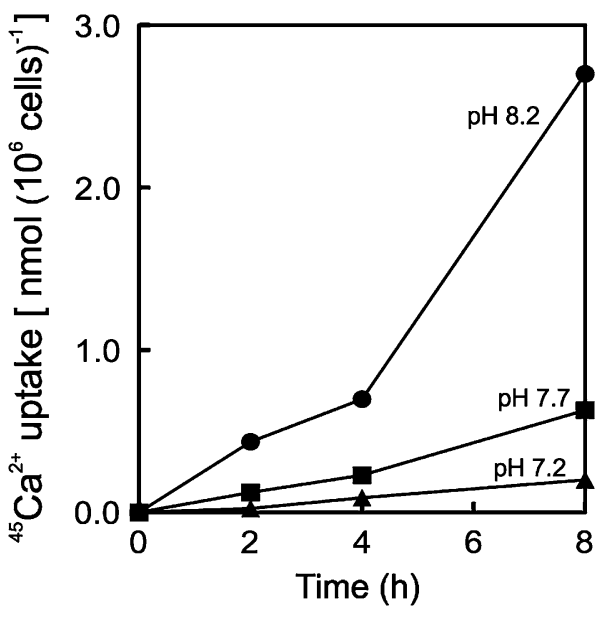

Fig. 5 Effect of the acidification by $\mathrm{HCl}$ on ${ }^{45} \mathrm{Ca}$-uptake by the coccolithophore E. huxleyi. In order to stimulate coccolith production, cells grown for 12 days were transferred to the orthophosphate-free medium for the radiotracer experiments. The concentration and the specific radioactivity of ${ }^{45} \mathrm{Ca}$ were $1 \mathrm{mM}$ as $\mathrm{CaCl}_{2}$ and $20 \mathrm{MBq} \mathrm{mmol}^{-1}$, respectively. Circles $\mathrm{pH} 8.2$; squares $\mathrm{pH} 7.7$; diamonds $\mathrm{pH} 7.2$

and the bubbling of elevated concentrations of $\mathrm{CO}_{2}$ in order to observe how coccolithophores respond potentially to acidification. The experimental conditions set in this study were not exactly the same as those expected in ocean acidification since seawater contained buffers to induce change in alkalinity. Cell density was also very high, and the rate of bubbling was not strong enough to get complete equilibration of inorganic carbons. Therefore, while the data we obtained are not directly applicable to the determination of the effect of ocean acidification on coccolithophores in the ocean, the data are still useful to predict how coccolithophores will respond to acidification physiologically. For this purpose, we analyzed the whole effect of acidification on cell growth, photosynthetic $\mathrm{O}_{2}$ evolution, photosystem's activity, Ca-uptake, the productivity of polysaccharides of AP and NP and coccolith production in the most abundant, bloom-forming coccolithophore, $E$. huxleyi.

When $\mathrm{pH}$ was simply decreased to 7.7 by acidification with $\mathrm{HCl}$, the specific growth rate of E. huxleyi was diminished $31.2 \%$ lower than that at $\mathrm{pH} 8.2$ and they rapidly died within 1 day at $\mathrm{pH} 7.2$ (Fig. 1a-d). In contrast, the acidification by $\mathrm{CO}_{2}$ enrichment by bubbling of 816 (lowest $\mathrm{pH}$ 7.6) and 1,192 ppm (lowest $\mathrm{pH}$ 7.5) slightly promoted algal growth (Fig. 1f-i). Those results indicate that $E$. huxleyi responds differently to acidification depending on whether it is accompanied by $\mathrm{CO}_{2}$ enrichment or not. The results also show that the diminution of algal growth by acidification with $\mathrm{HCl}$ can be overcome by an increase in $\mathrm{CO}_{2}$ supply. 
Fig. 6 Effect of the acidification by $\mathrm{HCl}$ on ${ }^{45} \mathrm{Ca}$ uptake by the coccolithophore E. huxleyi under growth conditions. a, b Time course of

${ }^{45} \mathrm{Ca}$-uptake in the presence of various $\mathrm{NaHCO}_{3}$ concentrations at $\mathrm{pH} 8.2$ and 7.7, respectively.

The numbers beside of lines in a represent the final concentrations $(\mathrm{mM})$ of $\mathrm{NaHCO}_{3}$ added to the medium: $N A$ (not added, filled diamond), 1 (filled triangle), 2 (open diamond), 5 (open circle), 10 (filled circle). c Relationship between ${ }^{45} \mathrm{Ca}$-uptake activity during $24 \mathrm{~h}$ and the final concentrations of $\mathrm{NaHCO}_{3}$ added to the medium. The numbers beside of $\mathrm{pH} 8.2$ line indicate the ratios of values at pH 8.2-7.7. d $\mathrm{HCO}_{3}{ }^{-}$ concentrations in the medium containing various concentrations (final) of $\mathrm{NaHCO}_{3}$ at $\mathrm{pH} 8.2$ and 7.7. The equilibration of inorganic carbons was calculated by $\mathrm{CO}_{2}$ SYS
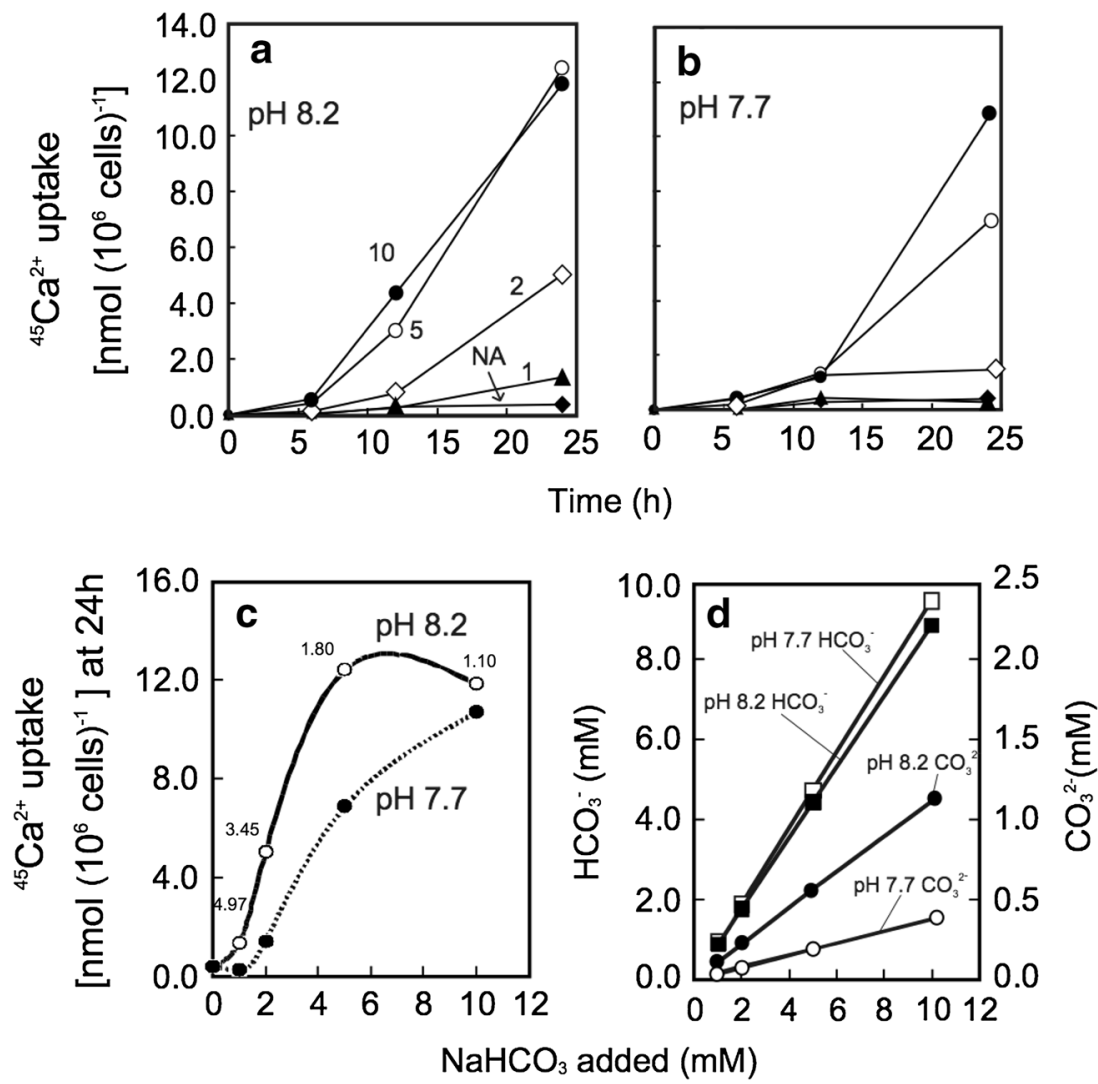

Acidification shifts DIC equilibrium toward $\mathrm{CO}_{2}$, and therefore, the concentration of total DIC becomes low when $\mathrm{pH}$ is decreased in an open system (Fig. 1e). Interestingly, bicarbonate concentration calculated was almost similar at $\mathrm{pH} 8.2$ and 7.7 at constant dissolved $\mathrm{CO}_{2}$ concentration under bubbling of air (Fig. 6d). The radiotracer experiment on ${ }^{45} \mathrm{Ca}$-uptake by E. huxleyi cells was performed to analyze the effect of acidification by $\mathrm{HCl}$ under bubbling of air with ca. $400 \mathrm{ppm}$. The results of the experiments clearly showed that ${ }^{45} \mathrm{Ca}$-uptake was strongly suppressed by acidification with $\mathrm{HCl}$ (Fig. 5). However, ${ }^{45} \mathrm{Ca}$-uptake was saturated with $5 \mathrm{mM}$ DIC at pH 8.2, but not enough with $10 \mathrm{mM}$ at $\mathrm{pH} 7.7$ (Fig. 6c), indicating that high bicarbonate concentration is required for calcification. This result agrees with evidence showing that only bicarbonate, not $\mathrm{CO}_{2}$, is the substrate for intracellular calcification on E. huxleyi (Sekino and Shiraiwa 1994). Although the influence of acidification on calcification of E. huxleyi has been reported (Zondervan et al. 2001; Riebesell et al. 2000; Langer et al. 2006; IglesiasRodriguez et al. 2008), the mechanism how acidification changes physiological status of coccolithophores has not been studied in detail. Therefore, the present result gives important information to elucidate how acidification by acid and by $\mathrm{CO}_{2}$ enrichment will be different.

In unicellular green alga Mesotaenium caldariorum, the high rate of ATP-dependent $\mathrm{Ca}^{2+}$-uptake and direct
$\mathrm{Ca}^{2+}$-transport $/ \mathrm{H}^{+}$-antiport activities was found to be necessary for $\mathrm{Ca}^{2+}$ uptake (Berkelman and Lagarias 1990). $\mathrm{Ca}^{2+}$. permeable channels in the plasma membrane were suggested more likely to function for $\mathrm{Ca}^{2+}$ entry into calcifying coccolithophore cells (Brownlee and Taylor 2003). $\mathrm{Ca}^{2+}$ accumulation into the Golgi of eukaryotic cells occurs by $\mathrm{H}^{+} / \mathrm{Ca}^{2+}$ exchange driven by the inside acidic $\mathrm{H}^{+}$electrochemical gradient across the Golgi membrane, which in turn is generated by V-type ATPase in eukaryotic cells (Harvey 1992). These previous reports show that acidification outside of membrane may disturb $\mathrm{Ca}^{2+}$ uptake through the $\mathrm{Ca}^{2+} / \mathrm{H}^{+}$ channel. The results support our conclusion that the suppression of $\mathrm{Ca}^{2+}$-uptake, calcification and coccolith production by E. huxleyi is due to the suppression of $\mathrm{Ca}^{2+}$-entry into cells by acidification of the medium (solid line in Fig. 8a). In addition, as the calcite saturation state is $<1$ in the low $\mathrm{pH}$ cultures, the coccoliths may also be dissolved even though coccoliths were produced and transported to the cell surface.

Acidification by $\mathrm{CO}_{2}$ enrichment promoted photosynthetic $\mathrm{O}_{2}$ evolution (Fig. 2), the morphological change in increase of cell volume, coccolith production (Fig. 4), $\mathrm{Ca}^{2+}$-uptake into cells (Fig. 6), and the production of acid (AP) and neutral polysaccharides (NP) (Fig. 7). On the other hand, acidification by both $\mathrm{HCl}$ and $\mathrm{CO}_{2}$ enrichment did not affect the activity of photosystem activities directly (Fig. 3). 

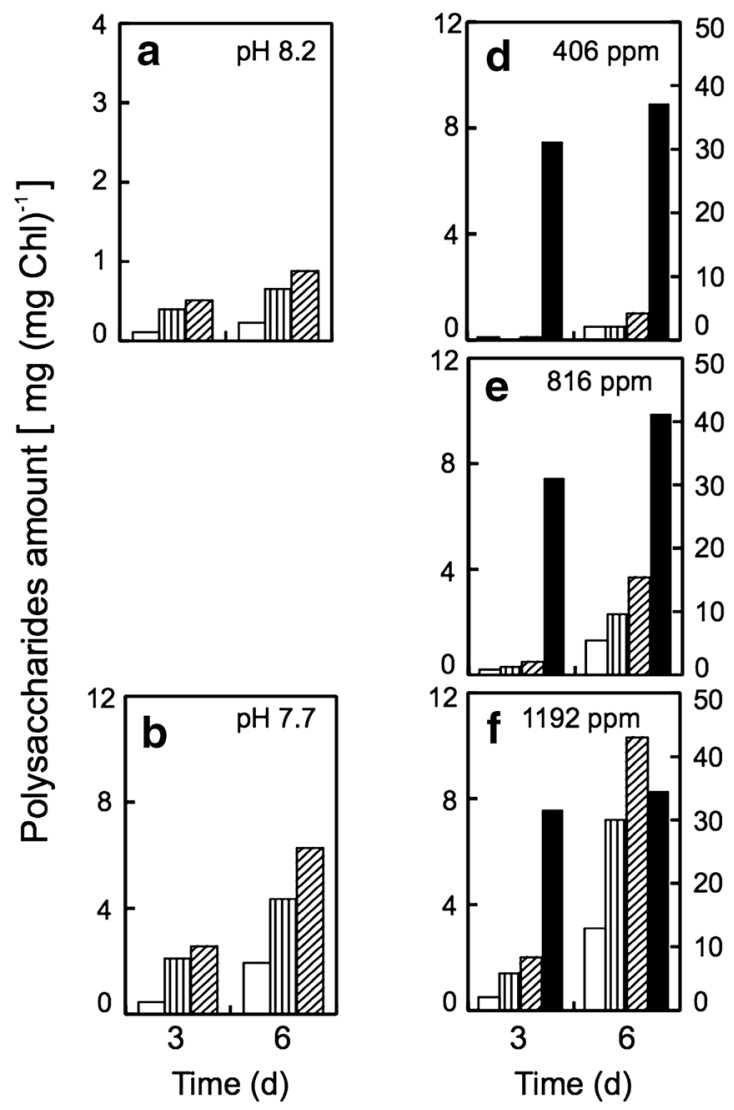

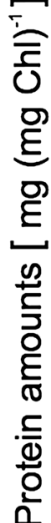

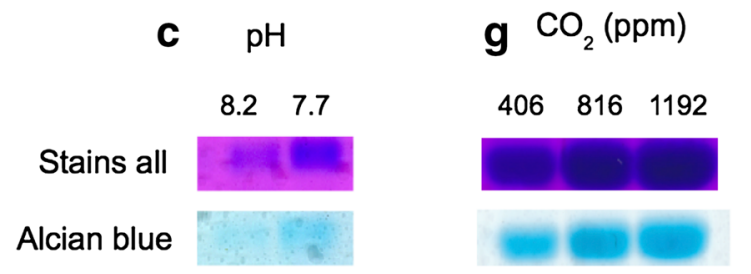

Fig. 7 Effect of the acidification by $\mathrm{HCl}(\mathbf{a}, \mathbf{b})$ and the ocean acidification conditions by elevating $\mathrm{pCO}_{2}(\mathbf{c}-\mathbf{e})$ on the production of polysaccharide and proteins by the coccolithophore E. huxleyi during 3 and 6 days under growth conditions. a, b At pH 8.2 and 7.7, respectively. d-f Under the bubbling of 406, 816 and 1,192 $\mathrm{ppm} \mathrm{CO}_{2}$ in air of which $\mathrm{pH}$ attained were 8.0-8.3, 7.6-7.9 and 7.5-7.7, respectively, as indicated in the figure. Before experiments, cells had been grown at $\mathrm{pH}$ 8.2. White column acid polysaccharides (AP) determined by the carbazole-sulfuric acid method; vertical stripe column neutral polysaccharides (NP) calculated by the equation of $[\mathrm{TP}]-[\mathrm{AP}]$; hatched column total polysaccharides (TP) determined by the phenol-sulfuric acid method; black bar protein contents determined by the protein assay kit (Bio-Rad Laboratories $\mathrm{AB}$ ). c, g Effect of acidification by $\mathrm{HCl}$ (c) and acidification by $\mathrm{CO}_{2}$ enrichment $(\mathbf{g})$, respectively, on SDS-PAGE image for the production of neutral and acid polysaccharides by the coccolithophore E. huxleyi grown for 6 days. The amount of cell used for analysis was corresponded to $5 \mu \mathrm{g}$ Chl. Total and acid polysaccharide bands were visualized by "Stains-all" and "Alcian blue," respectively

The state of photosystem II determined by $F_{\mathrm{v}} / F_{\mathrm{m}}$ and the electron transport activity of the whole photosystem ( $\phi$ PSII) of acidification were hardly changed by acidification during
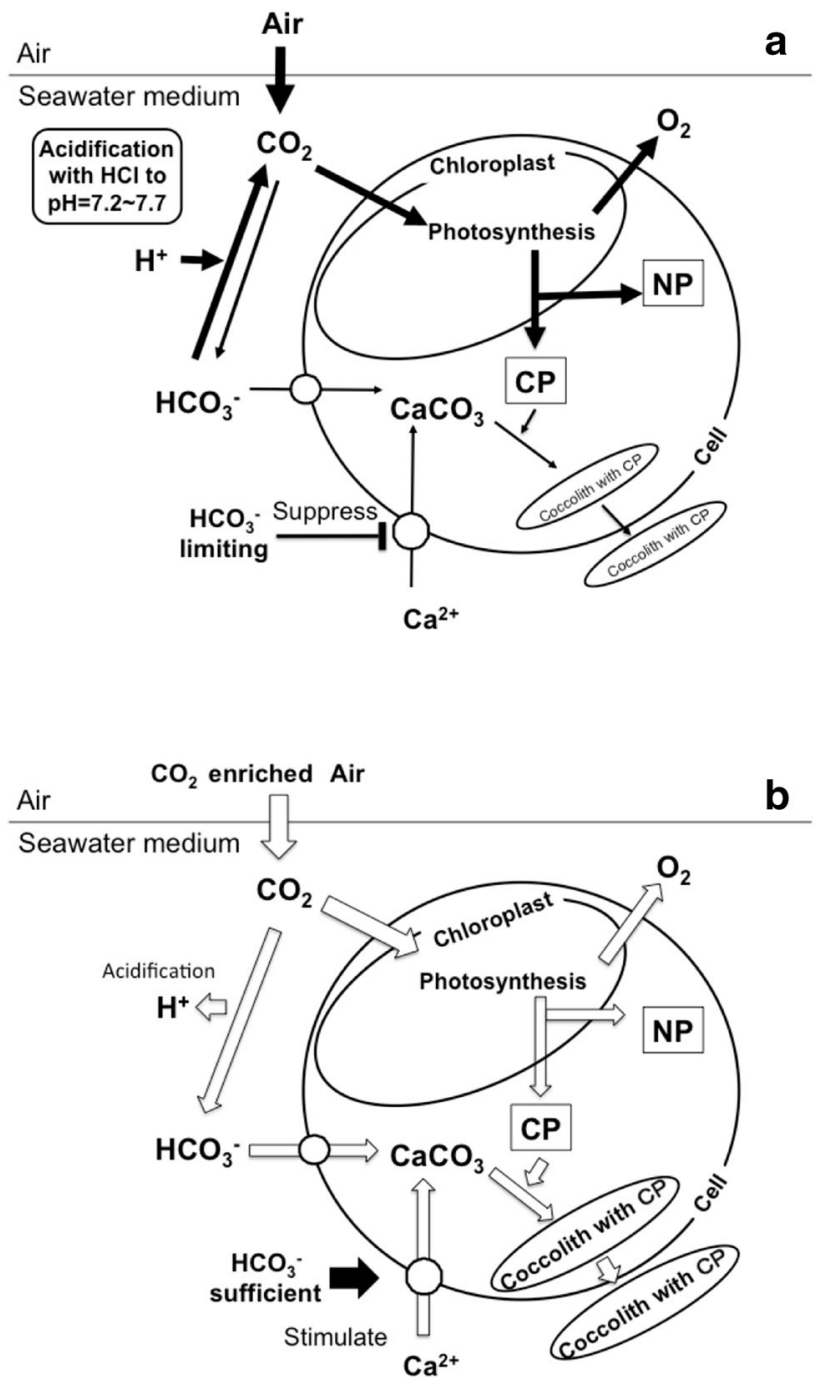

Fig. 8 Schematic models showing the effect of acidification by $\mathrm{HCl}$ (a) and by bubbling of air with elevated $\mathrm{CO}_{2}$ (b) on $\mathrm{CO}_{2}$ equilibration, inorganic carbon utilization for photosynthesis, $\mathrm{Ca}$ uptake and coccolith production by the coccolithophore E. huxleyi. The width of arrows represents the amount of compounds how much flow along the arrow. a Acidification by $\mathrm{HCl}$ changes in the equilibration between dissolved $\mathrm{CO}_{2}$ and bicarbonate toward $\mathrm{CO}_{2}$ production to decrease bicarbonate concentration. Dissolved $\mathrm{CO}_{2}$ concentration equilibrated with air bubbled was same among three $\mathrm{pH}$ conditions. The present study proved that the decrease in $\mathrm{HCO}_{3}{ }^{-}$ concentration suppressed coccolith production which is due to diminishing $\mathrm{Ca}^{2+}$-uptake by cells. Photosynthetic production of storage (NP) and coccolith polysaccharides (CP) was stimulated by acidification. b Acidification by $\mathrm{CO}_{2}$ enrichment increases dissolved $\mathrm{CO}_{2}$ concentration and bicarbonate production by increasing inorganic carbon substrates. The resulted increase in $\mathrm{CO}_{2}$ and bicarbonate which are substrate for photosynthetic $\mathrm{CO}_{2}$ fixation and intracellular calcification, respectively (Sekino and Shiraiwa 1994), stimulated both reactions. High concentration of bicarbonate also stimulated $\mathrm{Ca}-$ uptake. As a result, all those processes stimulated photosynthetic $\mathrm{CO}_{2}$ fixation and coccolith production

growth, irrespective of $\mathrm{pH}$ of the medium (Fig. 3a, b). In contrast, the $F_{\mathrm{v}} / F_{\mathrm{m}}$ values decreased under ocean acidification conditions where air with elevated concentration of 
$\mathrm{CO}_{2}$ was bubbled (Fig. 3c, e). The reason for the difference is unclear yet. These data are different from a previous report in which damage of photosystem II (PSII), namely decrease in $F_{\mathrm{v}} / F_{\mathrm{m}}$, by acidification in the thylakoid membrane of the green algae Scenedesmus obliquus (Heinze and Dau 1996). The possible explanation on the phenomena is that excess $\mathrm{CO}_{2}$ concentration in the medium induces high $\mathrm{CO}_{2}$ input into the chloroplast stroma and results in rapid acidification by the conversion of $\mathrm{CO}_{2}$ to bicarbonate plus $\mathrm{H}^{+}$by chloroplast carbonic anhydrases. Those reactions affect PSII directly and induced a decay of the $F_{\mathrm{v}} / F_{\mathrm{m}}$ value.

Acid (AP), same as coccolith polysaccharide (CP), and neutral polysaccharides (NP) determined as parameters of coccolith and storage polysaccharides (Kayano and Shiraiwa 2009), respectively, are known as coccolith polysaccharides containing uronic acids and storage polysaccharides composed of $\beta-1-3(1-6)$-glucan, respectively (Mann 2001; Kayano and Shiraiwa 2009). The amount of AP and NP production was stimulated by acidification, but the AP/NP ratio was not affected (Fig. 7). These phenomena may be due to an increase of $\mathrm{CO}_{2}$ supply into the cells and consequently the stimulation of the production of acid polysaccharides. Such active AP production also may stimulate $\mathrm{Ca}^{2+}$-uptake by demand of $\mathrm{Ca}^{2+}$ to produce $\mathrm{CaCO}_{3}$ crystals for coccoliths. Both cell size and coccolith production were affected by acidification with $\mathrm{CO}_{2}$ concentration (Fig. 4). Cell enlargement was also observed when coccolith production was strongly stimulated at low temperature (Sorrosa et al. 2005). As swelling of the cells were observed when cell growth was greatly suppressed by nutrient-deficiency or cell damage (Satoh et al. 2009), cell enlargement by acidification with $\mathrm{HCl}$ to $\mathrm{pH} 7.2$ might be due to cell damage. Satoh et al. (2009) and Kayano and Shiraiwa (2009) also reported that both coccolith and coccolith polysaccharide production were stimulated by phosphate deficiency from the medium, although the reason why cell size was enlarged by phosphate deprivation is still unclear.

Very recently, Bach et al. (2013) reported the results on analysis of impact of $\mathrm{CO}_{2}$ and $\mathrm{pH}$ on the mechanism of photosynthesis and calcification in E. huxleyi and concluded that E. huxleyi is sensitive to low $\mathrm{CO}_{2}$ and low bicarbonate as well as low $\mathrm{pH}$ beyond a limited tolerance range, but much less sensitive to elevated $\mathrm{CO}_{2}$ and bicarbonate. These results nicely fit to our present results although the parameters determined experimentally in both studies were different. The experiments by Bach et al. (2013) were performed by following carbon chemistry exactly, and therefore, their results can be extrapolated to the real ocean to simulate how E. huxleyi will be affected by ocean acidification. The present study clearly proved the mechanism behind how and why calcification, namely coccoliths production, is stimulated at elevated $\mathrm{CO} 2$ conditions and inhibited under acidification. Therefore, the combination of both papers is useful to understand how and why ocean acidification by increasing atmospheric $\mathrm{CO}_{2}$ will affect the physiology of the coccolithophore $E$. huxleyi.

In conclusion, the schematic model of the influence of acidification by acid (solid arrow) and by $\mathrm{CO}_{2}$ enrichment (open arrow) is shown in Fig. 8. The suppression of coccolith formation by acidification is shown to be due to the reduction of calcium uptake through the plasma membrane in E. huxleyi. On the other hand, photosynthetic machinery in the chloroplast was not affected by such acidification of the medium. This study proved that E. huxleyi cells have high potential of compensation to avoid damage of cells against acidification when acidification is caused by $\mathrm{CO}_{2}$ enrichment. This suggests that physiological activities of $E$. huxleyi cells will not be seriously damaged by ocean acidification at least up to $1,200 \mathrm{ppm} \mathrm{CO}_{2}$ in the atmosphere. However, as reported by Hoppe et al. (2011), there still is possibility that some ecophysiological difference and/or variation of $E$. huxleyi strains living in some specific habitats may induce some different response to ocean acidification.

Acknowledgments We thank that Dr. T. Midorikawa of the Meteorological Research Institute, Japan, for providing data on the equilibration of DIC species in the medium at various $\mathrm{pHs}$. We also appreciate very much for valuable suggestion and discussion to Dr. J. Toney of the University of Glasgow and anonymous reviewers. This study was supported in part by the Global Environment Research Fund from the Japanese Ministry of Environment to YS (FY2008-2010, F-083), the grant-in-aid of the Basic Research Area (S) by JSPS and MEXT to YS (FY2010-14) and the CREST, JST to YS (FY2011-15).

Open Access This article is distributed under the terms of the Creative Commons Attribution License which permits any use, distribution, and reproduction in any medium, provided the original author(s) and the source are credited.

\section{References}

Anthony KR, Kline DI, Diaz-Pulido G, Dove S, Hoegh-Guldberg O (2008) Ocean acidification cause bleaching and productivity loss in coral reef builders. Proc Natl Acad Sci USA 11:17442-17446

Bach LT, Mackinder LCM, Schulz KG, Wheeler G, Schroeder DC, Brownlee C, Riebesell U (2013) Dissecting the impact of CO2 and $\mathrm{pH}$ on the mechanism of photosynthesis and calcification in the coccolithophore Emiliania huxleyi. New Phytol 199:121-134

Berkelman T, Lagarias JC (1990) Calcium transport in the green alga Mesotaenium caldariorum. Plant Physiol 93:748-757

Bibby R, Cleall-Harding P, Rundle S, Widdicombe S, Spicer J (2007) Ocean acidification disrupts induced defences in the intertidal gastropod Littorina littorea. Biol Lett 3:699-701

Bijma J, Hönisch B, Zeebe RE (2002) Impact of the ocean carbonate chemistry on living foraminiferal shell weight: "Comment on carbonate ion concentration in glacial-age deep waters of the Caribbean Sea" by W.S. Broecker and E. Clark. Geochem Geophys Geosyst 3:1064. doi:10.1029/2002GC000388 
Bitter T, Muir HM (1962) A modified uronic acid carbazole reaction. Anal Biochem 4:330-334

Brownlee C, Taylor AR (2003) Calcification in coccolithophores: a cellular perspective. In: Thierstein $\mathrm{H}$, Young J (eds) Coccolithophores: from molecular processes to global impact. Springer, Berlin, pp 31-50

Caldeira K, Wickett ME (2003) Anthropogenic carbon and ocean pH. Nature 425:365

Danbara A, Shiraiwa Y (1999) The requirement of selenium for the growth of marine coccolithophorids, Emiliania huxleyi, Gephyrocapsa oceanica and Helladosphaera sp. (Prymnesiophyceae). Plant Cell Physiol 40:762-766

Demmig B, Bjorkman O (1987) Comparison of the effect of excessive light on chlorophyll fluorescence $(77 \mathrm{~K})$ and photon yield of $\mathrm{O}$, evolution in leaves of higher plants. Planta 171:171-184

Feely RA, Sabine CL, Lee K, Berelson W, Kleypas J, Fabry V et al (2004) Impact of anthropogenic $\mathrm{CO}_{2}$ on the $\mathrm{CaCO}_{3}$ system in the oceans. Science 305:362-366

Gattuso JP, Frankignoulle M, Smith SV (1998) Measurement of community metabolism and significance in the coral reef $\mathrm{CO} 2$ source-sink debate. Proc Natl Acad Sci USA 96:13017-13022

Genty B, Briantais JM, Baker NR (1989) The relationship between the quantum yield of photosynthetic electron transport and quenching of chlorophyll fluorescence. Biochim Biophys Acta 990:87-92

Hall-Spencer JM, Rodolfo-Metalpa R, Martin S, Ransome E, Fine M, Turner SM et al (2008) Volcanic carbon dioxide vents show ecosystem effects of ocean acidification. Nature 454:96-99

Harvey WR (1992) Physiology of V-ATPases. J Exp Biol 172:1-17

Heinze I, Dau H (1996) The pH-dependence of the photosystem II fluorescence: cooperative transition to a quenching state. Ber Bunsenges Phys Chem 100:2008-2013

Hodge JE, Hofreiter BT (1962) Determination of reducing sugars and carbohydrates. In: Whistler RL, Wolfrom MW (eds) Methods in carbohydrate chemistry, vol 1. Academic Press, New York, pp 380-394

Hoegh-Guldberg O, Mumby PJ, Hooten AJ, Steneck RS, Greenfield P, Gomez E et al (2007) Coral reefs under rapid climate change and ocean acidification. Science 321:51-52

Hoppe CJM, Langer G, Rost B (2011) Emiliania huxleyi shows identical response to elevated $\mathrm{pCO} 2$ in TA and DIC manipulations. J Exp Mar Biol Ecol 406:54-62

Iglesias-Rodriguez MD, Halloran PR, Rosalind EM, Rickaby REM, Hall IR, Colmenero-Hidalgo E et al (2008) Phytoplankton calcification in a High- $\mathrm{CO}_{2}$ world. Science 320:336-340

Intergovernmental Panel on Climate Change (IPCC) (2007) Summary for policy makers. In: Solomon $\mathrm{S}$ et al (eds) Climate change 2007: the physical sciences basis. Working group I contribution to the fourth assessment report of the IPCC. Cambridge University Press, Cambridge

Jeffrey SW (1972) Preparation and some properties of crystalline chlorophyll $c_{1}$ and $c_{2}$ from marine algae. Biochim Biophys Acta 279:15-33

Kayano K, Shiraiwa Y (2009) Physiological regulation of coccolith polysaccharide production by phosphate availability in the coccolithophorid Emiliania huxleyi. Plant Cell Physiol 50:1522-1531

Kleypas JA, Buddemeier RW, Archer D, Gattuso JP, Langdon C, Opdyke BN (1999) Geochemical consequences of increased atmospheric carbon dioxide on coral reefs. Science 284:118-120
Kuffner IB, Andersson AJ, Jokiel PL, Rodgers K, Mackenzie FT (2008) Decreased abundance of crustose coralline algae due to ocean acidification. Nat Geosci 1:114-117

Langer G, Geisen M, Baumann KH, Klas J, Riebesell U, Thoms S et al (2006) Species-specific responses of calcifying algae to changing seawater carbonate chemistry. Geochem Geophys Geosyst 7. doi: 10.1029/2005GC001227

Leuker TJ, Dickson AG, Keeling CD (2000) Ocean $\mathrm{pCO}_{2}$ calculated from dissolved inorganic carbon, alkalinity, and equations for $K_{1}$ and $K_{2}$ : validation based on laboratory measurements of $\mathrm{CO}_{2}$ in gas and seawater at equilibrium. Mar Chem 70:105-119

Liu H, Probert I, Uitz J, Claustre H, Aris-Brosou S, Frada M et al (2009) Extreme diversity in noncalcifying haptophytes explains a major pigment paradox in open oceans. Proc Natl Acad Sci USA 106:12803-12808

Mann S (2001) Biomineralization: principles and concepts in bioinorganic materials chemistry. Oxford University Press, Oxford

Miles H, Widdicombe S, Spicer JI, Hall-Spencer J (2007) Effects of anthropogenic seawater acidification on acid-base balance in the sea urchin Psammechinus miliaris. Mar Pollut Bull 54:89-96

Orr JC, Fabry VJ, Aumont O, Bopp L, Doney SC, Feely RA et al (2005) Anthropogenic ocean acidification over the twenty-first century and its impact on calcifying organisms. Nature 437:681-686

Read BA, Kegel J, Klute MJ, Kuo A, Lefebvre SC, Maumus F et al (2013) Pan genome of the phytoplankton Emiliania underpins its global distribution. Nature 499:209-213

Richier S, Fiorini S, Kerros ME, Peter von Dassow PV, Gattuso JP (2010) Response of the calcifying coccolithophore Emiliania huxleyi to low $\mathrm{pH} / \mathrm{high} \mathrm{pCO} 2$ : from physiology to molecular level. Mar Biol 158:551-560

Riebesell U, Zondervan RostB, Tortell PD, Zeebe RE, Morel FMM (2000) Reduced calcification of marine plankton in response to increased atmospheric $\mathrm{CO}_{2}$. Nature 407:364-367

Ross PM, Parker L, O'Conner WA, Bailey EA (2011) The impact of ocean acidification on reproduction, early development and settlement of marine organisms. Water 3:1005-1030

Satoh M, Iwamoto K, Suzuki I, Shiraiwa Y (2009) Cold stress stimulates intracellular calcification by the coccolithophore, Emiliania huxleyi (Haptophyceae) under phosphate-deficient conditions. Mar Biotechnol 11:327-333

Sekino K, Shiraiwa Y (1994) Accumulation and utilization of dissolved inorganic carbon by a marine unicellular coccolithophorid, Emiliania huxleyi. Plant Cell Physiol 35:353-361

Sorrosa JM, Satoh M, Shiraiwa Y (2005) Low temperature stimulates cell enlargement and intracellular calcification of coccolithophorids. Mar Biotechnol 7:128-133

Swift E, Taylor W (1966) The effect of $\mathrm{pH}$ on the division rate of the coccolithophorid Cricosphaera elongata. J Phycol 2:121-125

Veron JE, Hoegh-Guldberg O, Lenton TM, Lough JM, Obura DO, Pearce-Kelly P et al (2009) The coral reef crisis: the critical importance of $<350 \mathrm{ppm} \mathrm{CO}$. Mar Pollut Bull 58:1428-1436

Zeebe RE, Zachos JC, Calderia K, Tyrrell T (2008) Carbon emissions and acidification. Science 321:51-52

Zondervan I, Zeebe RE, Rost B, Riebesell U (2001) Decreasing marine biogenic calcification: a negative feedback on rising atmospheric $p \mathrm{CO}_{2}$. Glob Biogeochem Cycles 15:507-551 